\title{
DISCOURSE DEPUTY REGENT OF SAMPANG IN 2017 IN MUSREMBANG LEADERSHIP
}

\author{
Abdul Chakim \\ Media \& Communication Study Program, Universitas Airlangga, Surabaya, Indonesia \\ Email: abdulchakim7@gmail.com
}

\begin{abstract}
Regent of Sampang in 2017 was replaced by the Deputy Regent. The Sampang Regent cannot lead the musrembang forum because of his health condition. The leadership replaced by the Deputy Regent must show the leadership model which is supposed to be. The attitude shown is as if it were the main leader. Success musrembang forum depending on how the deputy regent can manage, work together and lead all participants in this forum.This study aims to analyze the musrembang discourse in the leadership of the vice regent of Sampang. The methodology in this study uses discourse analysis which leads to Analysis of the Van Dijk Model. This model concerns three parts of analysis. They are textual analysis, social cognition, and social context. While textual analysis is based on speech texts, social cognition and context analysis are based on the external and what's behind the discourse. This research led to the leadership model as shown by the Deputy Regent of Sampang in the text of the Musrenbang speech and why this speech text (related to content) was produced. First, the leadership model can be seen from the textual context in the speech text. Second, why this speech text can be produced can be seen from cognition and social context. Thus, the three approaches of the Van Dijk Model Analysis can lead to two conclusions. They are the types of leadership models and the background of the production of this speech text. The results of this study are expected to be considered as recommendations for the next Regent in 2019.
\end{abstract}

Keywords: Leadership, discourse analysis, van dijk's model, politics.

Submited: 26-10-2018; Accepted: 30-04-2019; Published: 30-04-2019

*Korespondensi: Media \& Communication Study Program, Universitas Airlangga

Kampus B Jl. Dharmawangsa Dalam, Surabaya, Jawa Timur 60286

Email: abdulchakim7@gmail.com 


\section{INTRODUCTION}

A leader can be a medium to create goals simultaneously through his leadership. The leadership model can be created by the way he works or leads (Faules 2010). Then, related to what Musrenbang is a term for development planning forums. Musrenbang will also be the topic of discussion in this paragraph (Ningsih 2018). This discussion starts from forums from the lowest administrative level to the district level to the City level. Musrenbang is an open multi-forum that simultaneously identifies and decides the priorities of community development policies. This forum can be used as a process of negotiation, reconciliation and harmonization of differences between the government and non-government sectors. It also became a forum for consensus in achieving the priorities of development programs and budgeting plans.

The theoretical approach, applied in this study, is the theory of leadership and discourse analysis. First, leadership theory is used to categorize leadership models as shown in the Musrenbang Speech Text. Second, discourse analysis is used to analyze the texts of Musrenbang speeches, social cognitions and the social context of the text. The discourse concerns the leadership model. Then, the text of the Musrenbang speech was analyzed using the Teun A Van Dijk discourse model. This model will group the analysis into three parts. They are textual, social cognition and social context. The concept of leadership can be understood as a process for carrying out a goal that can affect individuals or groups with specific goals or aspirations. Leadership can also be said as a direction which influences the activities of others (Najib 2013).

Why do researchers need to analyze the leadership of the Deputy Regent of Sampang? This question indeed motivates researchers because the success of Musrenbang can be seen how a leader is able to direct, manage and motivate all SKPD leaders and all elements of civil society. In addition, the Musrenbang conducted this year is the last development planning forum in its last government period. He was a single warrior leader because his colleague from the Sampang district was sick. So, the dual role of being a representative of the Regent must be done to accelerate and succeed the process of governance and development in Sampang. Why the Sampang Deputy Regent's discourse of leadership, also as Sampang Regent, in 2017. "District Musrenbang" Speech The true text was raised 
as the main issue in this study because this might be a reference for the next Regent selected 2018.

\section{RESEARCH THEORY}

The research method used in this study, is a method of discourse analysis. Using the Van Dijk Model Analysis, this study deals with textual analysis, social cognition, and social context.The term discourse (discourse) originating from Latin discourse, has been used both in a limited and broad sense. In limited terms, this term refers to the rules and habits that underlie the use of language in both oral and written communication. More broadly, the term discourse refers to language in actions and patterns that characterize the types of languages in action. In contemporary large dictionaries there are three meanings. First, conversation, speech, and speech.Second, the whole speech or conversation which is a unit. Third, the largest, most complete language unit whose realization is in the form of a complete composition, such as novels, books, and articles in critical discourse analysis other than the text also in context, namely language can function as a tool and practice achieving goals, including ideological practices (Payuyasa 2017). As also expressed by Eriyanto regarding the position of language in the view of critical discourse as follows, "Language in critical view is understood as a representation that plays a role in shaping certain subjects, certain discourse themes, and strategies in them."(Paturusi 2009).

In reality, the form of discourse can be seen in the various works of the creator. discourse: Text (discourse in the form of writing), among others, forms of news, articles, novels, Talks (discourse in the form of speech), among others in the form of recordings, interviews, actions (in the form of action) and Arifact(Discourse in the form of traces) (Astuti 2011). we can find the existence of this form of discourse in print, visual and audiovisual media.

According to Van Dijk, research on discourse is not enough based solely on text analysis, because text is only the result of a production practice that must also be observed. Here it must also be seen how a text is produced so that it obtains a knowledge of why the text can be like that. Text is not something that comes from the sky, nor is it an independent vacuum. However, text is formed in a discourse practice, a discourse practice (Sobur 2006). To illustrate his model van Dijk made 
a lot of analysis studies on media coverage. Discourse according to van Dijk has three dimensions or buildings, namely text, social cognition, and social context. The essence of van Dijk's analysis is to combine these three dimensions of discourse into one unitary analysis. In the dimensions of the text, what is examined is how the structure of the text and discourse strategies are used to assert a particular theme. At the level of social cognition the process of producing news texts is studied which involves individual cognition from journalists (text makers). While the third aspect of studying the building of discourse that develops in society will be a problem. Van Dijk's analysis as a whole connects textual analysis which focuses solely on the text, towards a comprehensive analysis of how the text is produced, both in relation to individual journalists and from the community.

Van Dijk sees a text consisting of several structures / levels which each support each other. He divided it into three levels(Dijk 2019). First, macro structure. This is the global / general meaning of an observable text with a topic or theme put forward in a news story. Second, the superstructure. Is a discourse structure that relates to the framework of a text, how the parts of the text are arranged into the news as a whole. Third, micro structure is the meaning of discourse that can be observed from a small part of a text, namely words, sentences, propositions, clauses, paraphrases, and images (Dijk 1995). According to Van Dijk, although it consists of various elements, all these elements constitute a single entity, are interconnected and support each other.

The difference in the method of discourse analysis with other methods in terms of value, is that language is an object of research that has an important role in its discussion. Language becomes the focus of the discussion and is assessed from various perspectives, including how a language process is produced and its reproductive process, which is considered as the beginning of the framework of a discourse issued (Dijk 2002). In the more remote domains, then language is seen as a form of the constellation of power and the existence of dominant groups, the use of language is also considered a media of propaganda, a tool used by a group to marginalize other groups.

The subjects in the study were the speech text of the Sampang 2017 Musrenbang. Then, the object of the study was the discourse of the Deputy Regent of Sampang's leadership in the District Musrenbang Speech 2017. The 
Chakim:Discourse Deputy Regent of

Sampang in 2017 in Musrembang

Le a d e rship

study used a descriptive-qualitative research approach. Data obtained from the results of this study by collecting documentation on the text of the Musrenbang speech in Sampang in 2017. This study is supported by literature reviews of related books, journals, articles and other supporting sources considered secondary data in this study.

Certain uses of words, sentences, propositions, rhetoric are understood by Van Dijk as part of the strategy of the text maker. The use of certain words, sentences and certain styles is not merely seen as a way of communicating, but is seen as a politics of communication, namely a way to influence public opinion, create support, strengthen legitimacy, and get rid of opponents or opponents(Sampang 2017).

\section{RESULTS AND DISCUSSION}

\section{The Deputy Regent of Sampang's Discourse of Text Analysis}

\section{Macro Structure (Themes)}

Thematic elements or themes show a general description of a text, also can be referred to as the main idea, the main summary of the text. The word "theme" is also referred to as the topic. Topics describe what a communicator wants to express (Eriyanto 2006). The text of this speech reveals the theme of cooperation. One theme was found, as follows:

Cooperation was shown in the initial explanation of the speech text of how a Deputy Regent of Sampang welcomed one by one SKPD leaders who were present at the opening of the SampangMusrenbang. SKPD is a regional work unit. The opening began by welcoming SKPD strategic leaders especially in the development sector, the Deputy Regent of Sampang also asked them how they could unite their vision and mission in carrying out regional development programs. The following is the beginning of the text of the speech delivered by the Deputy Regent of Sampang:

"Today we gather together to unite our determination, thoughts, and steps to discuss regional development programs in Sampang Regency in 2018, and at the same time to increase more effective cooperation. ... "(p.2)

"Today, we gather to unite our will, thoughts, and strong steps in planning regional development programs for Sampang 2018 and also enhance more effective cooperation ..." (p. 2) 
The above article is a quotation from the contents of the text of the speech delivered. In the quotation above, the Deputy Regent of Sampang clearly emphasized the people who attended the Musrenbang forum to unite the willingness of hard work, thoughts and steps proposed by Sampang II, what was done to make the development program planned in theMusrenbang blueprint successful.

\section{Schemes Super Structures (Schemes)}

Super Structural schemes are texts or discourses which generally have chronological plots from beginning to end. Superstructure or scheme usually uses three structures(Eriyanto 2006). Framework of a text, such as the introduction, fill in the closing, and conclusions. The superstructure observed is the schematic section of how the sections and the sequence of news in the theme in the news text are intact. The element that is the subject of the discussion is the scheme. According to van Dijk, the important meaning of schematics is the strategy of journalists to support certain theories that they want to convey by arranging parts in a certain order. Schematics puts pressure on which parts take precedence and which parts can later as a strategy to hide important information. Text or discourse generally has a scheme or plot from the introduction to the end. The flow shows how the parts in the text are arranged and sorted to form a unified meaning(Lado 2014)

Beginning. At the beginning of the text of this speech, the Deputy Regent of Sampang, besides addressing the head of the SKPD related to the Musrenbang's strategic development program. The Deputy Regent of Musrembang asked all elements of the community to succeed in this development program. Then, the leaders of the two Sampang began to explain what and how the Musrenbang was. Here, it seems to refresh the memories of all participants about the essence of the Musrenbang and also tell them how they should behave or respond to Musrenbang programs.

Conflict. In this conflict plot, the Deputy Regent of Sampang explicitly explained which programs failed or were unable to reach the expected targets. Then, his speech was directed at flood disaster management. It is said that annual floods have destroyed public facilities. These facilities are always programmed at 
Chakim:Discourse Deputy Regent of

Sampang in 2017 in Musrembang

Le a d e rship

every opportunity for Musrenbang. However, what was shown was apparently not in accordance with the high budget for this flood management program. These problems, explained by the Deputy Regent of Sampang, showed that he appointed the SKPD head who must be responsible for the previous programs.

Resolution. At the end of the forum for the Musrenbang speech delivered by the Deputy Regent of Sampang, he spoke about his last period of government. It lasts less than a year. Here, he explains which programs should be prioritized and which are not. In addition, he also gave prizes to two SKPDs that successfully achieved the target of the previous Musrenbang program. The prize was given to them, namely Sampang and Camplong districts.

\section{MicroStructure}

Semantic. Analysis in the Van Djik critical discourse analysis scheme is categorized as local meaning. In this event the local meaning can have multiple meanings(Susilo 2017). Considering that language is used as a medium to lead issues, interests, and also submit opinions. The semantics or meanings that you want to emphasize in the text can be seen from several things such as background, details, intentions, and presuppositions. Background, details and intentions relate to which information is emphasized and get more portions. Meanwhile the element of presupposition is a statement used to support the meaning of a text.

Not all discourse texts that appear contain certain intentions, but interesting things deserve to be studied. The following are described data as well as discussions related to the semantic domain. Semantics is a linguistic study involving the meaning of language which states that in the semantics discussed is the relationship between the word and the concept or meaning of the word, as well as objects or things referred to by that meaning which are outside the language. The meaning of a word, expression or discourse is determined by the existing context(Petada 2001). Semantic elements are explained below:

Setting.Sematic is a part of text that can influence the meaning conveyed, arrangement reflects ideology or principle of communicator (Petada 2001). In the text of this speech, the 2017 SampangMusrenbang was held at the Regent's General Hall. This event was occupied by the strategic head of the SKPD (regional work unit) which determined the construction sector of public facilities 
to representatives of civil society. Then, the text of this speech conveys the SKPD which has the lowest realization of the previous program, the conditions after the annual flood, and priorities that must be resolved. Based on the facts above then the situationwhich shows the concern of the Deputy Regent of Sampang. This concern does have several reasons. First, less than one year the government will end but some programs have not been completed. As a result, why did he speak explicitly about which SKPD could not meet the program targets clearly rationally.

Details of the. Information submitted is in the form of controls delivered by the communicator (Petada 2001). A communicator will show information excessively that can benefit himself and he will show the least information that can make him lose big. Details in the text of this speech can be seen from this quote:

"Sampang District needs to be visited by smart people so that its communities can become smart." (P.16)

"Sampang Regency needs to be visited by many smart people to make Sampang people smart" $(P .16)$

The sentence conveyed seems to have a satirical message about the original condition of Sampang. Then, the Regent of Sampang called "smart people". This condition is an indication that he seems to have camouflage against previous programs that failed or were unsuccessful.

Mean. The meaning is an element that sees whether a text is delivered explicitly or implicitly (Petada 2001). In the text of this speech, it can be seen from the quote below:

"The problem of flood management in the Sampang city area, we ask for personal assistance to all communities affected by the flood." (P.14)

"Disaster management issues, especially catastrophic floods in downtown Sampang, we personally ask for your forgiveness especially for people who are directly affected by this disaster. "(p.14)

In the quotation above, it is clear that a leader acknowledges his mistakes and requests forgiveness from his people in front of the Musrenbang forum. Apology, delivered by a leader, is very rarely done. It's related to pride. Not all leaders can apologize to their people. But the Deputy Regent of Sampang said that in front of the Musrenbang Forum. 
Syntax. Syntax is a part or branch of science or language that talks about the subtleties of discourse, sentences, clauses and phrases. In syntax there is coherence, sentence form and pronouns. Of the three are the results of manipulating politics in showing themselves positively and the opponent becomes negative by using syntax (sentences). The sentence in this research is a sentence that is in the text of the musrenbang speech. Discussion about this sentence unit is how a word or sentence is arranged so that it can become a single entity (Parera 2003).

Coherence. Coherence is a boundary of words or sentences, usually can be identified using conjunctions: and, but, or, because etc(Parera 2003). This term can be seen in the quote below:

"We invite all members of the community and all development stakeholders to work hand in hand together,"

"We invite all elements of society and all construction stakeholders to work

$$
\text { together..." }
$$

Placing the word "and" in the musrembang speech indicates that the second leader or deputy of the Sampang Regent. The Deputy Regent of Sampang is not only asking for civil society participation but also in three sectors that technically support the development sector for the development to take place.

SentenceThe sentence. Structurestructure is a syntactic element related to logical thinking, explaining about propositions arranged in a series of sentences. This quote can explain and distinguish which objects, subjects, verbs and supplements. Syntax relates to how the sentence is chosen. Syntax can be seen from coherence, denial, sentence form, and pronouns (Parera 2003).

"We recognize that development achievements during our leadership are still far from the expectations of the community..." (p.9)

"We realize that the realization of development programs during our period may be far from

SV Conj Adverbclauses

Hopeof the Sampang community.

Adverb Clause

We voice what meant by the construction of the

Conjunction Session Clause Description

during our leadership is still far from the expectations of the community

Clause Description 
From the explanation above, the sentence is a complex series which is found in many clauses and conjunctions. top A complex sentence with a clause in one sentence series indicates that there is a message or more additional information that must be conveyed.In addition, sentences with long clauses also show a causal relationship from one paragraph to another paragraph

Pronouns. Pronouns Is a tool used by communicators to show the position of se a person in a discourse (Parera 2003). The pronoons used in this speech text are "Me" and "We". Following are the contents of the musrembang forum speech text.

"... With sincerity we thank you as high as possible to the ladies and gentlemen who have been willing to attend this forum." (P.2)

"... with our sincere hearts, we would like to thank and appreciate all those who already in this forum. "(P.2)

From the text quote above, an analysis can be drawn that the Deputy Regent of Sampang uses the pronoun" us ". This shows that he is not the leader of a single fighter in carrying out a development program but how the need for cooperation or what is called a team, working with him, can succeed the program well.

"... I submit the results of the evaluation of the SampangMusrenbang

Monitoring Team ..." (p.17)

"... I will announce the evaluation results from the Musrenbang monitoring team ..." (p.17)

Use of pronouns "I" like the quote above, most similar speech texts apply this to direct or point objects. This term is used in the text of the District Musrenbang speech to convey problems related to program targets that failed or were unsuccessful. So, the use of "I" indicates a personal relationship between the communicator and the recipient. As a result, this is not the relationship of leaders and institutions but rather personal relationships. The Deputy Regent of Sampangpersonally expressed his praise, dissatisfaction, and advice to the designated recipient. By using "I", it means that a leader does not need a mediator or assistant to give orders, praise or advice but he immediately points to everyone he wants.

Style Style.Style or model is Modelclosely related to social representation, namely how views, beliefs, and prejudices develop in society (Ashari 2015). The text of the speech at the musrenbang forum has a view in the community. 
However, how these beliefs influence will be influenced by experience, memory, andinterpretationthisshows how one chooses words based on the possibilities available(Parera 2003).

"Ladies and Gentlemen, who I respect" "Ladies and Gentlemen, the Musrenbang participants(honored ... ")

In the above quote, the Deputy Regent of Sampang used the word"brother"(address in the official situation) as the first greeting for Musrenbang participants. In formal speeches, it is common to use "brothers". But in this context, that must be a different case because a leader uses it. This can show that a leader wants to reduce the gap with his people. He might want to be recognized by his people as his brother. This is not a matter of formal protocol for a leader but how a leader can listen to what is desired and complained about by the people.

Rhetoric. Rhetoric is related to how and with how the emphasis is made. Rhetoric can be seen from the use of graphics, metaphors and expressions. Graphics see the use of graphics, images, or tables to support the importance of a message. Graphic elements provide cognitive effects, in the sense that they control attention and interest intensively and show that information is important and must be considered. Models to explain intonation or pressure (Parera 2003). Elements are divided into Graphics and Metaphors.My graphis part of checking what someone emphasizes in a text (Parera 2003). As quoted below:

"Improving Basic Service Quality, Disaster Management and Regional Economic

Competitiveness Towards a Dignified Sampang Regency". (p.9)

"Improving the quality of public services, disaster management and regional economic competitiveness is for the sake of the prestige of Sampang." (p.9)

The above quote is in a bold format because the Deputy Regent of Sampang wants to emphasize what the final target and output of all planned programs are. By using bold format, everyone can show which points need to be prioritized and which points are not necessary, especially in the case of the Musrenbang program. Writing bold format is also used to describe what I need to do and important points.

Metaphor. Metaphor is used as ornamental text, usually figurative speech and proverbs (Parera, 2003). Metaphors are also used as self-conceptualizations as 
mental structures which include views on humans, social roles and events. In the text of this speech, the use of metaphors is rarely applied because what is conveyed here is about the realization and targets of previous programs. As a result, figurative figures of speech are avoided to convey more assertive meanings. Even so, at the end of his speech, the Sampang second leader used this satirical figurative speech as follows:

"Sampang District needs to be visited by smart people so that its people will be smart." (P.16)

"Sampang District needs to be visited by people smart people to make Sampang people smart. "(p.16)

It seems that the Deputy Regent of Sampang in the content of the speech text is a sarcastic language for the incompetent people of Sampang. Deputy Buapati realized that the sampan community was less competent, so it was necessary to visit as a means to improve the community's composition. This can be seen from the contents of the text conveyed by the Deputy Regent of Sampang in the content of the text of his speech deafening the sentence. By using such figurative speeches, he hopes that the Sampang community can be more professional and competent. The main competencies expected by the Deputy Regent of Sampang in terms of work culture. This insinuating speech does not mean ridicule. The text of the speech above on the other hand also can increase the enthusiasm of the Musrenbang participants for the success of the development program. So that the running of the Musrembang was in accordance with what was expected by the Deputy Regent of Sampang.

\section{Deputy Regent's Leadership Discourse of Sampang from Social Cognition} Analysis

Using the Van Dijk Model in discourse analysis, he does not only focus on the text but also from the point of view of the communicator. This can be social cognition or social context.Social cognition looks at how a text is produced. Social cognition is related to the mental awareness that forms the text(Mansoer 2001). Departing from Van Dijk's idea that the text itself does not have meaning, it is given by the process of mental awareness of language users. The regent or deputy regent is not seen as a neutral individual, but an individual who has various values, experiences, and ideological influences gained from his life. 
Van Dijk mentions that events are understood and understood according to the scheme. Schemes are conceptualized as mental structures in which they cover how we view humans, social roles, and events. There are several types of schemes / models that can be described in this case (Mulyana 2005). This social cognition analysis is focused on how text can be produced, understood, and interpreted. In the process of writing speech texts, communicators, the Deputy Regent of Sampang included his ideas in this text. In addition, expert staff in the fields of economics and development also participated in making the text of this speech. For additional information, the Deputy Regent of Sampang came from PPP (a political party in Indonesia) and also three skilled staff members were drawn from prospective party members. As a result, prioritized and recommended programs can be adopted from the party's perspective. The leaders of the two Sampang will also become elected judges from the PPP for the next regional election in 2018.

Speaking of the text of the 2017 District Musrenbang speech, communicators explicitly explain which sectors cannot reach the target and which do not. Then, there was an apology from the leaders of the two Sampang because there were several programs that could not be maximized properly or even failed. Programs that run well later are given prizes. The awarding of prizes was given to SKPD (Regional work units that succeeded in achieving the expected targets.

\section{Deputy Regent of Sampang Leadership Discourse from the Social Context}

The final discussion of Van Dijk's Discourse Analysis is the social context. The social context comes from external text so that the basis of communicators write or convey their ideas The meaning of this can be lived out, taking points from the contents of the text, social power produced through discourse and legitimacy practices, according to Van, are there two important components in the social context, namely the practice of satisfaction and access.

In the social context the practice of power is defined as ownership by a certain group or member to control members and other groups. This is called domination, because it can indirectly influence one another. Another reason is that it can influence the location and context of the content of the speech. Second is access in influencing discourse. The intended access is as the majority have 
greater access than minorities. the majority of the majority is more likely to gain access or control in influencing discourse.

According to the second leader or vice regent of Sampang, why does he explicitly explain which SKPD cannot meet the estimated targets and which are not all because of the low value of LAKIP (the term for government work performance reports). Therefore he needs to be frank to the SKPD which cannot reach the target.Then, there are several priority programs that must be done. Because his reign lasted less than one year. So, at the end of his administration, he hoped all the priority programs could be resolved properly.So, there are two reasons why the text of this speech is explicitly conveyed. First, because the LAKIP score is low and the second is because of his reign.

\section{CONCLUSION}

All in all, the leadership discourse, represented in the text of this speech, leads to the middle ground style. This is based on what is explained by Blake and Mouton in the Managerial Grid Theory. This is supported by data found in macro structures, themes, superstructures (including how this speech began inviting all participants to the success of the Musrerenbang program, explaining sectors that failed to reach the target estimates, explained priority programs and asked for apologies about programs failed), micro structure (including the complexity of the structure of the language indicated by long sentence clauses, this can mean that a leader is very detailed in managing and directing his staff), the style of speech in this speech is a strict text. On the other hand, there was a style of greeting that could be a different point of view from the Deputy Regent of Sampang. The address word "brother" is generally used in Indonesian speech texts. But it will be different and interesting while a leader often applies the word "brother" in his speech. This can mean that a leader tries to approach and be closer to the staff or people. As a result, there will be no gap between the leader and his staff or the people. The metaphor displayed in this text is rarely found because the Deputy Regent of Sampang wants to deliver a speech explicitly to avoid misunderstanding and misleading its meaning.

From social cognition and context, it can be concluded why this Deputy Regent Sampang leadership discourse is categorized as a middle road style. According to the analysis above, the LAKIP score is still CC. As a result, he is 


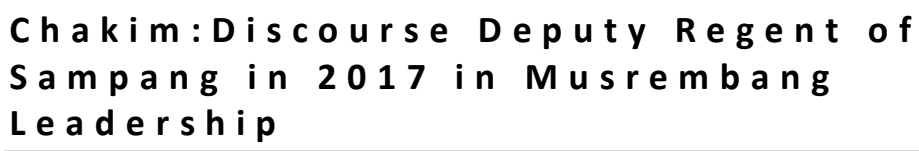

worried about how to work together and solve program problems that have not been completed. He is not an authoritative leader but a participatory person who is open to accepting suggestions and considering advice from all elements of society. Then, his reign will last less than one year. That made him worry that his development program could not be completed as an expected target.

\section{REFERENCES}

Ashari, Afif. 2015. "Meaning Constraction Of Slogans Used By The President Candidates The General Election (Pemira) UB 2011." Universitas Brawijaya Malang.

Astuti, Tia Agnes. 2011. "Analisis Wacana van DIJK Terhadap Berita Sebuah Kegilaan Di Simpang Kraft Di Majalah Pantau.” UIN Syarif Hidayatullah Jakarta.

Dijk, Teun Van. 1995. “Aims of Critical Discourse Analysis.” Japan Discourse 1.

Dijk, Teun Van. 2002. “A Sociocognitive Apporache.” Critical Discourse Studies.

Dijk, Teun Van. 2019. "Menganalisis Rasisme Melalui Analisis Wacana Melalui Beberapa Metodologi Reflektif."

Eriyanto. 2006. Analisis Wacana: Pengantar Teks Miedia. Yogyakarta: LKiS.

Faules, R. Wayne Pace dan Don F. 2010. Komunikasi Organisasi: Strategi Meningkatkan Kinerja Perusahaan. Bandung: PT Remaja Rosadakarya.

Lado, Rico. 2014. "Analisis Wacana Kritis Program Mata Najwa 'Balada Perda' Di Metro TV.” 2(2).

Mansoer, P. 2001. Semantik Leksikal. Jakarta: Rineka Cipta.

Mulyana. 2005. Kajian Wacana: Teori, Metode, Aplikasi Dan Prinsip-Prinsip Wacana. Jakarta: Tiara Wacana.

Najib, Ainun. 2013. "Kontruksi Pemimpin Ideal Untuk Indonesia.” Jurnal Agama Dan Hak Asasi Manusia 3(1).

Ningsih, Sulis Tia and Ucha Jaya Sucipta Jaya Sucipta and Maurina Suryaning Pertiwi. 2018. "Imajinasi Desa Impian: Konstruksi Media dalam Pengembangan Desa Wisata di Desa Ranuklindungan Kabupaten Pasuruan." The Journal of Society and Media. 2(1): 65-80.

Parera, JD. 2003. Sintaksis. Jakarta: Gramedia.

Paturusi, IA. 2009. "Esensi Dan Urgenitas Peraturan Daerah Dalam Pelaksanaan Otonomi Daerah." 1.

Payuyasa. 2017. “Analisis Wacana Kritis Model Van Dijk Dalam Program Acara Mata Najwa Di Metro TV.” Seni Rupa Dan Seni Denpasar 5.

Petada, M. 2001. Semantik Leksikal. Jakarta: Rineka Cipta.

Sampang, H. 2017. "Sambutan Pidato Musrenbang Kabupaten 2017.” 
50 | The Journal of Society and Media 3(1)

Sobur, A. 2006. Analisis Teks Media: Suatu Pengantar Untuk Analisis Wacana, Analisis Semiotik Dan Analisis Framing. Bandung: PT Rosadakarya.

Susilo, Daniel. 2017. "Wacana Maskulinitas Dalam Teks Media: Sebuah Tinjauan Kritis Atas Berita Kekerasan Dalam Situs Berita Online.” 30(4). 